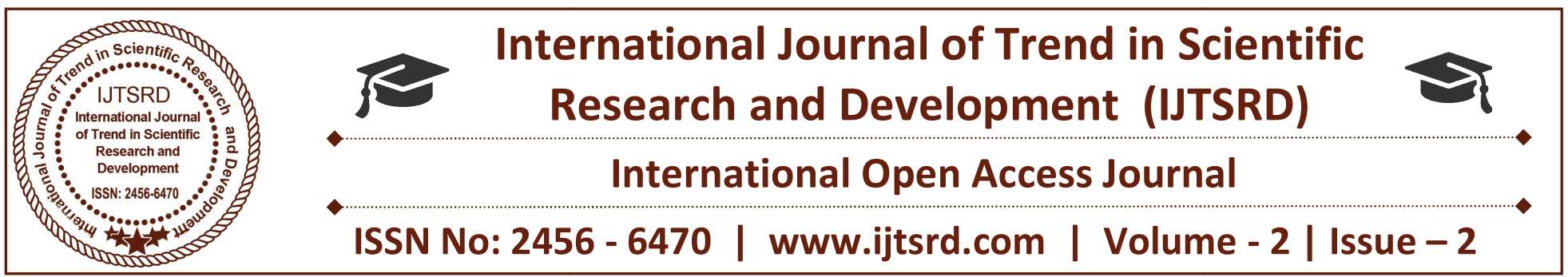

\title{
ICICI Bank and Services for Society
}

\author{
Dr. Pushpa Suryavanshi \\ Assistant Professor, Dr. Hari Singh Gour Central \\ University Sagar, Madhya Pradesh, India
}

\section{ABSTRACT}

Services give us more satisfaction for our life, these are visible or not visible but it's provide those satisfaction do not give us more money. In this condition for satisfaction and complete our ambitions banking play an important role for our society and it is a most important institution for our society. The sector plays an important role in economic development of a country. It is a pillar for any strong nation economy. An efficient banking system is recognized as the prime requirement for the overall progress of any nation. The banking system of India is featured by the large network of bank branches, providing more services not only customers but to the nation also. Banks are most important institutions for our financial and non-financial requirements. Actually bank provides more facilities for our life. In India networking of bank branches are very large.

According to Narsimham committee "Private sector bank should be allowed to be established in India these new private sector banks will complement the overall financial sector reforms". ICICI bank is most popular and second largest bank in private sector. ICICI Bank services provided and cooperated with peoples for his necessity or needs. It is a private bank, so this study based on the various types of services provided by ICICI Bank with private sector comparatively government sectors banks and in this time private banks are very powerful and they give strongly highly facilities and services with competition for government banks.

Keywords: ICICI, Services, Facilities, Government Sector, Private Sector, Economic Development etc.

\section{INTRODUCTION}

An efficient banking system is recognized as the prime requirement for the overall progress of any nation. Bank is a most important institution of our society; banks give him more financial and nonfinancial support for our necessity. Without bank or finance we cannot suffer in our life, every step of our life we wants finance but money is not useful or important for every condition. We want services for satisfaction of our life. Finance and services both are our necessity, so without systematically process we all cannot suffer in our life or our society, so banking sector is most important for our systematically life.

Banks are those sector he give him financial or nonfinancial support. In this time life move very fast and this modern life all wants more facilities. According to before and after conditions of banks are very changed. The banks (Government with Private) give him various facilities and government or private banks always tried to give him better for our society. In this time both type of banks give various facilities in all areas, so every type of bank wants well working, facilities, process, complete satisfaction, customer's choice etc.

\section{ICICI BANK PROFILE}

ICICI Bank is a second largest and leading bank of private sector in India. It does headquarter in Mumbai, India. ICICI Bank was established by the Industrial Credit and Investment Corporation of India (ICICI), AN Indian financial institution, as a wholly owned subsidiary in 1994. The present company was formed in 1955 as the joint-venture of the World Bank. The 
bank was initially known as Industrial Credit and Investment Corporation of India before it changed its name to the abbreviated ICICI Bank. ICICI bank became the first Indian bank to list on the New York Stock Exchange and his network cover with 19 countries including India. 84096 total numbers of employees, 4,850 branches and 14,404 in ICICI Bank.

\section{OBJECTIVE OF THE STUDY}

1. To analysis the progress of ICICI bank.

2. To analysis the financial performance of ICICI bank.

3. To examine the various types of services provided by ICICI Bank.

4. To Examine the growth of customers with services provided by ICICI Bank

5. To study selected years 2008-09 to 2014-15 for financial performance of ICICI Bank.

\section{RESEARCH METHODOLOGY}

In the present study, an attempt has been made to examine the various types of services provided by ICICI Bank and analysis the financial performance of ICICI bank which one related to the private sector. The study is based on secondary data that has been collected from other secondary sources. The study covers the period of 2008-09 to 2014-15.

\section{LIMITATIONS OF THE STUDY}

Due to constraints of time and resources, the study is likely to suffer from certain limitations. The limitations of the study are:

1. The study is based on secondary data and only focus on private sector with ICICI Bank.

2. The secondary data are collected from other sources for analysis the financial performance and examine the various types of services for customer growth of ICICI bank.
3. This study based on the only 2008-09 to 2014-15 years.

\section{DATA ANALYSIS PERCENTAGES \\ RESPONDENTS HAVING ACCOUNT IN ICICI BANK}

Pie Chart: 1

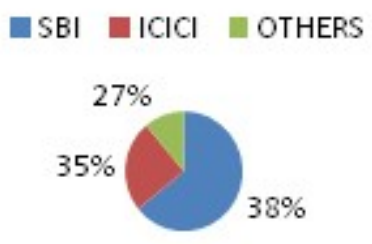

Pie Chart.1 showing the respondents of customer related with banks accounts. $38 \%$ customers like the

\begin{tabular}{|l|l|l|}
\hline YEAR & ICICI & \\
\hline & NO. OF BRANCHES & ADDITIONAL MADE \\
\hline $2008-09$ & 1419 & ----- \\
\hline $209-10$ & 1707 & 288 \\
\hline $2010-11$ & 2529 & 822 \\
\hline $2011-12$ & $\mathbf{2 7 5 0}$ & $\mathbf{2 2 1}$ \\
\hline $2012-13$ & $\mathbf{3 1 0 0}$ & $\mathbf{3 5 0}$ \\
\hline $2013-14$ & $\mathbf{3 7 5 3}$ & $\mathbf{6 5 3}$ \\
\hline $2014-15$ & $\mathbf{4 0 7 0}$ & $\mathbf{3 1 7}$ \\
\hline
\end{tabular}

SBI, 35\% customers like the ICICI and $27 \%$ customers like the other banks for our transactions, deposit of cash and other needs.

\section{NO. OF BRANCHES IN ICICI BANK}

(TABLE. 1)

\section{Source: compiled from annual report of ICICI}

By observing table no.1 showing that the ICICI bank has more number of branches. It is a private bank but Year by year growth of branches of continues grow till the date.

\section{NUMBERS OF ATMs IN ICICI BANK (Graph. 1)}

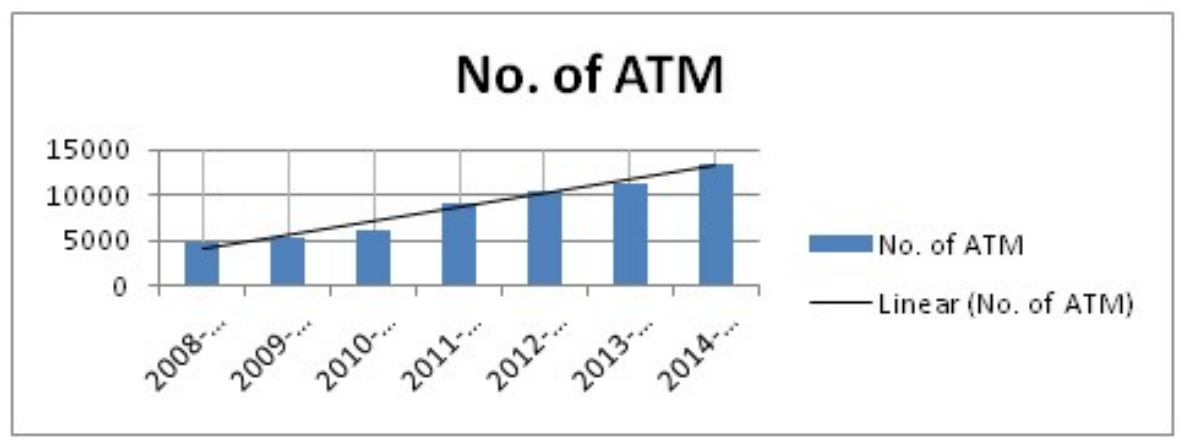


By observing graph no.1 drawn very easily that ICICI growth of ATMs has been continuing in banks. Highly growth of branches in year 2011-12 and lowest growth is in year 2013-14 in ICICI Bank.

Source: compiled from annual report of ICICI

\section{DEPOSITE, NET PROFIT AND TOTAL INCOME IN ICICI BANK (IN CRORES)(Graph. 2)}

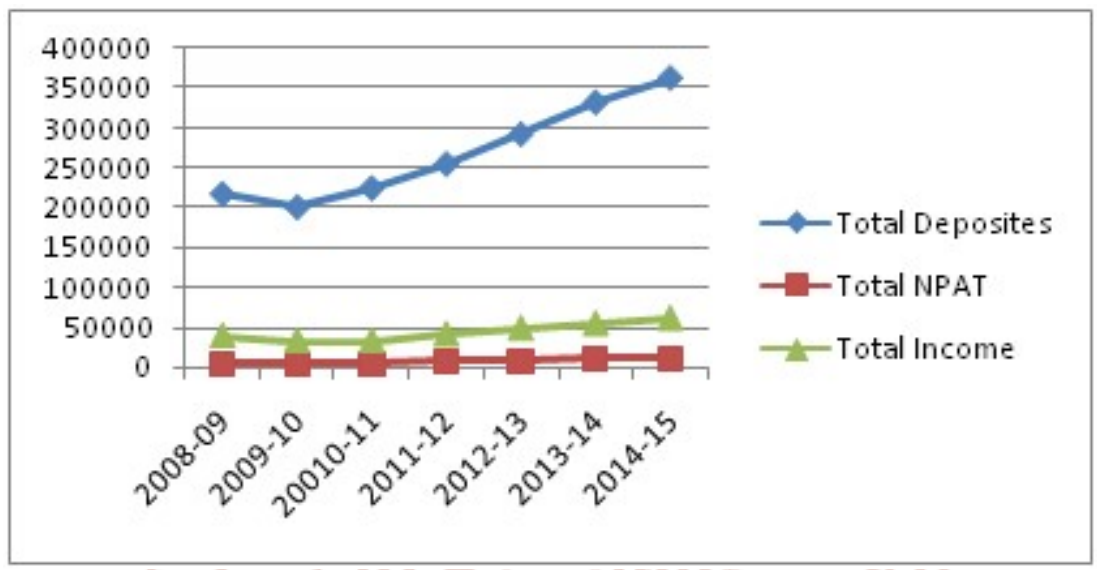

\section{Source: compiled from annual report of ICICI}

By observing the graph no.2, show that the growth of amount of deposits net profit and total income continues increasing in ICICI Bank.

\section{SERVICES OFFERED BYICICI BANK}

Management Accounts

$>$ Funds Transfer

$>$ Card less Cash Withdrawal

$>$ Recharge Prepaid Mobile/DTH Connection

$>$ Pay Utility Bills

$>$ Credit Card Payments

$>$ ICICI Bank Fixed Deposits/Recurring Deposits

$>$ Fixed Deposits

$>$ ICICI Bank Recurring Deposits

$>$ Internet Banking

$>$ Mobile Banking

$>$ Pockets by ICICI Bank

$>$ Find ATM / Branch etc.

\section{Management Accounts}

The ICICI and other banks provided services for Check account balance and amount, View last transactions, Check Credit card details, Send Cheque book request Stop Cheque request etc. for according to customers wishes.

\section{Funds Transfer}

Customers suffer many problems when his amount not transfers for his complete purpose, so ICICI bank gives us facilities for fund transfer. Transfer funds to own ICICI Bank account, other ICICI Bank account and non-ICICI Bank account using NEFT service from anywhere using online. It is a secure and easy way to transfer funds to own ICICI Bank account, other ICICI Bank account and non-ICICI Bank account using NEFT mode of fund transfer.

\section{Card less Cash Withdrawal}

Card less Cash Withdrawal service is a simple and safe mode for you to send cash, to any mobile number anywhere place in India with your Internet Banking user ID and password and initiate a Card less Cash Withdrawal transaction. The recipient need not have any bank account or an ATM card, and can withdraw cash from over 10,000 ICICI Bank ATMs across India, using the details received through SMS.

\section{Recharge Prepaid Mobile/DTH Connection}

Present time everyone are busy, all are want safe money and save time, so bank say good bye to running out of talk time or missing your favorite shows by recharging your prepaid mobile and DTH connection on the go and at your own comfort with ICICI Bank.

\section{Pay Utility Bills}

With the convenience of ICICI Bank Internet Banking on your mobile, you can pay your bills anytime, from anywhere. Avoid long queues by registering your billers and pay all your utility bills - electricity, gas, phone/mobile etc. on time with safe mode. 


\section{Credit Card Payments}

ICICI Bank provide Credit Card bring to you convenience coupled with absolute safety and unparalleled discounts. In addition, we have taken a step further to provide you convenience on the go. You can now pay your credit card bills with ICICI bank.

\section{ICICI Bank Fixed Deposits/Recurring Deposits}

Small saving amount of money solves long problems of running life. Now you can open an ICICI Bank Fixed Deposit or Recurring Deposit using ICICI bank. Save money using just your mobile phone, from the comfort of your according place anywhere of India.

\section{Fixed Deposits}

Saving amount activities is a part of life with different sources of finance or others. Be it saving for 7 days or a decade, you can trust ICICI Bank Fixed Deposits for attractive interest rates. Additionally, you have the freedom to make premature withdrawals, get a loan or overdraft of up to $90 \%$ of your FD amount; and choose monthly or quarterly payouts of your according savings.

\section{ICICI Bank Recurring Deposits}

Recurring deposits are a way to manage regular payments smoothly and simple. With a deposit of minimum Rs. 500 per month, you can begin with tenure of 6 months and thereafter, in multiples of 3 months with bank.

\section{Internet Banking}

ICICI bank provides many services for customers with internet or online banking. Explore the power of simpler and smarter banking. Bank online with over 250 different types of services for different demands according to customers.

\section{Mobile Banking}

Bank on the go with our Mobile Banking services with uses SMS and provides us services with one click on mobile.

\section{Pockets by ICICI Bank}

VISA powered Universal payment wallet, we can use in any country for lack of currency according to other country for our solution of problems or difficulties.

\section{Find ATM/Branch}

Bank 24 hours through a widespread network with various facilities with ATM/ Branch we can use for any financial depositing and transfers of money.

\section{CONCLUSION}

Bank is a most important part of our society. An efficient banking system is recognized as the prime requirement for the overall progress of any nation. Many numbers of banks stable and play an important role of societies. They give much financial supports of society and customers but without non- financial services all customers are not satisfy and banks not give us complete satisfaction. In this present time more competition with others institutions, so all banks are provides financial and non financial services for satisfaction of customers. Services are visible and not visible but they give satisfaction we cannot comparison with money. ICICI is the second largest private sector of bank, is far better than others because is flying continuously towards the sky is many of the observations and provides various services for his customers. Per branch performance of ICICI is better than in majority of the cases which reflects the efficiency and managerial skills of the bank, and if the situation will remain same ICICI may take a lead in Indian banking industry in terms of profitability in near future. Banks activities implementation and services are most important for any nation society.

\section{REFERENCES}

1. Service Marking, Writter V. Sharma \& Sanjay Gupta, Edition 2015.

2. Banking and Financial Institutions, Writter Dr. V. C. Sinha \& Dr. Pushpa Sinha, Edition 2015.

3. Monetary Theories and Financial Institutions, Writter Dr. Satish Kumar Saha, Edition 2016.

4. Money and Financial Systems, Writter Dr. V. C. Sinha \& Dr. Pushpa Sinha, Edition 2015.

5. RBI statistical table (2014-15)

6. Annual report of RBI (2008-09 to2014-15)

7. Annual report of ICICI (2008-09 to 2014-15)

8. Tactful Management Research Journal.

9. www.icicibank.com

10. www.rbi.co.in 